\title{
Chemical Carcinogenesis in the Nervous System
}

\section{PREFERENTIAL ACCUMULATION OF $O^{6}$-METHYLGUANINE IN RAT BRAIN DEOXYRIBONUCLEIC ACID DURING REPETITIVE ADMINISTRATION OF $N$-METHYL- $N$-NITROSOUREA}

\author{
By GEOFFREY P. MARGISON* and PAUL KLEIHUES $\dagger$ \\ Max-Planck-Institut für Hirnforschung, Abteilung Allgemeine Neurologie, \\ 5 Cologne 91, West Germany
}

(Received 13 January 1975)

\begin{abstract}
1. The alkylation of purine bases in DNA of several rat tissues was determined during weekly injections $(10 \mathrm{mg} / \mathrm{kg})$ of $N-\left[{ }^{3} \mathrm{H}\right]$ methyl- $N$-nitrosourea, a dose schedule known to selectively induce tumours of the nervous system. Each group of animals was killed 1 week after the final injection, and the DNA hydrolysates were analysed by chromatography on Sephadex G-10. 2. After five weekly applications, $O^{6}$-methylguanine had accumulated in brain DNA to an extent which greatly exceeded that in kidney, spleen and intestine. In the liver, the final $O^{6}$-methylguanine concentration was less than $1 \%$ of that in brain. Between the first and the fifth injection, the $O^{6}$-methylguanine/7-methylguanine ratio in cerebral DNA increased from 0.28 to 0.68 . In addition, 3-methylguanine was found to accumulate in brain DNA whereas in the other organs no significant quantities of this base were detectable. 3 . The results are compatible with the hypothesis that $O^{6}$-alkylation of guanine in DNA plays a major role in the induction of tumours by $N$-methyl- $N$ nitrosourea and related carcinogens. 4 . The kinetics of the increase of $O^{6}$-methylguanine in cerebral DNA suggest that there is no major cell fraction in the brain which is capable of excising chemically methylated bases from DNA. This repair deficiency could be a determining factor in the selective induction of nervous-system tumours by $N$-methyl- $N$ nitrosourea and other neuro-oncogenic compounds.
\end{abstract}

$N$-Methyl- $N$-nitrosourea is a potent carcinogen which, under certain dose schedules, selectively induces tumours of the nervous system (Druckrey et al., 1967). The carcinogenicity of $N$-methyl- $N$ nitrosourea has been attributed to its ability to alkylate nucleic acids in the intact animal. Among the various reaction products, $O^{6}$-alkylguanine in DNA has received particular attention, since this base has been suggested to be promutagenic (Loveless, 1969) and was found to miscode in an RNA polymerase system in vitro (Gerchman \& Ludlum, 1973). There is recent indication that the capacity of different rat tissues to remove $O^{6}$-alkylguanine from DNA may correlate with the organ-specific carcinogenic effect of $N$-methyl- $N$-nitrosourea and related alkylnitrosoureas (Goth \& Rajewsky, 1974; Kleihues \& Margison, 1974). After a single injection of $N$ methyl- $N$-nitrosourea in adult rats, $O^{6}$-methylguanine is eliminated more slowly from cerebral DNA than from that of kidney and liver (Kleihues \& Margison, 1974). However, a single dose $(60-80 \mathrm{mg} /$ $\mathrm{kg}$ ) causes the development of tumours in various rat tissues, whereas the selective induction of nervous-

* Present address: International Agency for Research on Cancer, Lyon, France.

$\dagger$ To whom reprint requests should be addressed. system tumours has been shown to follow repetitive low doses (Druckrey et al., 1965, 1967; Jänisch \& Schreiber, 1969; Swenberg et al., 1972). We have therefore determined the concentrations of $O^{6}$ methylguanine in DNA of various tissues during weekly injections of $N-\left[{ }^{3} \mathrm{H}\right]$ methyl- $N$-nitrosourea $(10 \mathrm{mg} / \mathrm{kg})$, i.e. a dose schedule which eventually would have led to the production of nervous-system tumours in most experimental animals. Under these conditions, $O^{6}$-methylguanine was found to accumulate in brain DNA to an extent which greatly exceeded that of any other organ investigated.

\section{Experimental}

Animals

Female BD-IX rats (Druckrey, 1971) were used. At the beginning of the experiment, body weights were 103-109g.

\section{Chemicals}

$N$-[ $\left.{ }^{3} \mathrm{H}\right]$ Methyl- $N$-nitrosourea $(45.5 \mathrm{mCi} / \mathrm{mmol})$ was obtained from NEN Chemicals, Dreieichenhain, West Germany. For injection it was dissolved in 
3 mm-sodium citrate (pH6.0). Unlabelled $N$-methyl$N$-nitrosourea was added to give a specific radioactivity of $26.3 \mathrm{mCi} / \mathrm{mmol}$. Bovine pancreatic ribonuclease (EC 3.1.4.22) was obtained from Boehringer, Mannheim, West Germany. For use it was dissolved in water $(2 \mathrm{mg} / \mathrm{ml})$ and heated to $80^{\circ} \mathrm{C}$ for $10 \mathrm{~min}$ to inactivate contaminating deoxyribonucleases.

\section{Animal experiments}

$N-\left[{ }^{3} \mathrm{H}\right]$ Methyl- $N$-nitrosourea was injected into the femoral vein under light ether anaesthesia at a dose of $10 \mathrm{mg} / \mathrm{kg}$. Animals were divided into five groups, each consisting of two rats. Group 1 received a single injection and was killed 1 week later. The other groups received two to five injections at weekly intervals and were killed 1 week after the final injection.

\section{Isolation of DNA}

Animals were killed by exsanguination under ether anaesthesia. Organs were frozen in liquid $\mathrm{N}_{2}$ and stored at $-70^{\circ} \mathrm{C}$. DNA was isolated by phenol extraction as follows. Tissues were allowed to thaw in $6-10 \mathrm{vol}$. of $6 \%(\mathrm{w} / \mathrm{v})$ sodium $p$-aminosalicylate containing $1 \% \mathrm{NaCl}$, and subsequently homogenized by hand in a loose-fitting Teflon-glass homogenizer. The homogenate was shaken with an equal volume of phenol reagent (phenol-m-cresol-8-hydroxyquinoline-water, 100:14:0.1:11, w/v/w/v) for $30 \mathrm{~min}$ at room temperature $\left(22^{\circ} \mathrm{C}\right)$. After centrifugation for $30 \mathrm{~min}$ at $4^{\circ} \mathrm{C}$ and $16000 \mathrm{~g}$, the phenol phase was similarly re-extracted with $0.5 \mathrm{vol}$. of the sodium p-aminosalicylate- $\mathrm{NaCl}$ mixture. The combined supernatants were made $3 \%(\mathrm{w} / \mathrm{v})$ with respect to $\mathrm{NaCl}$ and extracted with $0.5 \mathrm{vol}$. of the phenol reagent. To the viscous aqueous phase was added $2 \mathrm{vol}$. of ethanol-m-cresol $(9: 1, \mathrm{v} / \mathrm{v})$, and after repetitive inversions the precipitate was spooled out on to a glass rod and extracted with $3 \mathrm{ml}$ of $3.0 \mathrm{M}$ sodium acetate. After centrifugation for $20 \mathrm{~min}$ at $13000 \mathrm{~g}$ and $5^{\circ} \mathrm{C}$, the precipitate was extracted twice more with $3 \mathrm{ml}$ of sodium acetate and the crude DNA precipitated from the combined supernatants by addition of 2 vol. of cold 2-ethoxyethanol. The DNA was dissolved in $3 \mathrm{ml}$ of water and dialysed against 2 litres of water for approx. $4 \mathrm{~h}$ at $4^{\circ} \mathrm{C}$. RNA contaminants were degraded by overnight incubation at $4^{\circ} \mathrm{C}$ after addition of ribonuclease solution $(0.4 \mathrm{ml}$, $2 \mathrm{mg} / \mathrm{ml})$ and saturated sodium acetate $(0.15 \mathrm{ml})$. The purified DNA was precipitated with 2 vol. of 2ethoxyethanol, washed several times with cold ethanol, dried and stored at $-20^{\circ} \mathrm{C}$.

\section{Analysis of purine bases}

DNA $(5-10 \mathrm{mg})$ was hydrolysed in $1.0 \mathrm{ml}$ of $0.1 \mathrm{M}-\mathrm{HCl}$ at $37^{\circ} \mathrm{C}$ for $17 \mathrm{~h}$ (Lawley \& Thatcher,
1970). The purine bases were loaded on columns $(90 \mathrm{~cm} \times 1 \mathrm{~cm})$ of Sephadex G-10 and eluted with $0.05 \mathrm{M}$-ammonium formate, pH6.8 (Lawley \& Shah, 1972). Authentic marker compounds (3-methyladenine, 3-methylguanine, 7-methylguanine and $O^{6}$ methylguanine) were added to some hydrolysates. Their elution positions relative to adenine were identical with those reported by Lawley \& Shah (1972), except for 3-methyladenine, the elution of which depends on the $\mathrm{pH}$ of the applied sample (Goth \& Rajewsky, 1974). After the extinction at 260 and $280 \mathrm{~nm}$ had been measured, fractions $(4.5 \mathrm{ml})$ were transferred to plastic counting vials and dried in a stream of air. The residue was dissolved in $0.3 \mathrm{ml}$ of $1 \mathrm{M}$-Hyamine hydroxide in methanol and counted for radioactivity for $50 \mathrm{~min}$ after the addition of $10 \mathrm{ml}$ of toluene containing $0.5 \%(\mathrm{w} / \mathrm{v}) 2,5$-diphenyloxazole and $0.05 \%(\mathrm{w} / \mathrm{v}) \quad p$-bis-(o-methylstyryl)benzene. Quench correction was by external standardization, counting efficiency being approx. $40 \%$. The background radioactivity was stable at 29-31d.p.m./ fraction.

Amounts of methylguanines present were expressed as $\mathrm{mol} \%$ of guanine, taking the molar extinction coefficient of guanine at neutral pH to be 7200 litre. $\mathrm{mol}^{-1} \cdot \mathrm{cm}^{-1}$ and assuming that their specific radioactivity was the same as that of the methyl group of the injected $N$ - $\left[{ }^{3} \mathrm{H}\right]$ methyl- $N$-nitrosourea (Swann \& Magee, 1968; Lawley \& Shah, 1973). The amount of radioactivity in the $O^{6}$-methylguanine peak varied from 0 to 42 d.p.m. (liver) and 1200 to 4300 d.p.m. (brain). Occasionally, guanine and adenine were not completely separated. The $E_{280} / E_{260}$ ratios of these bases at neutral $\mathrm{pH}$ are 1.02 and 0.11 respectively. It was therefore possible to calculate the relative amounts of guanine and adenine in each of the overlapping fractions.

By using pairs of animals, the variation in the amount of 7-methylguanine determined in different experiments was found to be less than $6 \%$. The estimation of minor alkylation products may vary to a greater extent according to the absolute amount of radioactivity present.

\section{Results}

Fig. 1 shows elution profiles from Sephadex G-10 of DNA hydrolysates from animals which received five weekly injections of $N-\left[{ }^{3} \mathrm{H}\right]$ methyl- $N$-nitrosourea. Marked differences can be seen in the pattern of alkylated purines in liver and brain. In both organs, 7-methylguanine is the major reaction product, but in the brain there are also substantial amounts of $O^{6}$-methylguanine, measurable quantities of 3methylguanine and traces of 3-methyladenine. These minor alkylation products are virtually absent from the liver. The absolute amounts of 7-methylguanine 


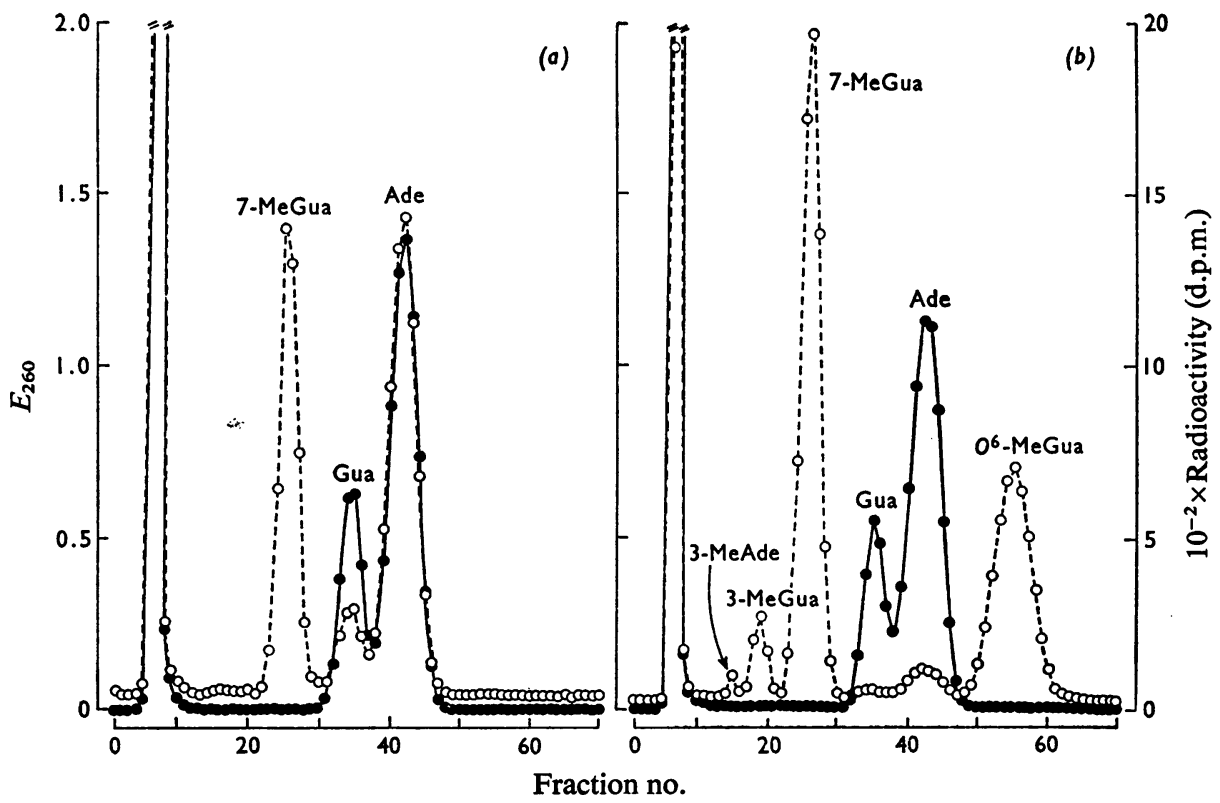

Fig. 1. Fractionation of the purine bases of DNA from rat liver (a) and brain (b)

Animals received five weekly injections of $N-\left[{ }^{3} \mathrm{H}\right]$ methyl- $N$-nitrosourea $(10 \mathrm{mg} / \mathrm{kg})$ and were killed 1 week after the final injection. DNA was isolated, hydrolysed and chromatographed on Sephadex G-10 as described in the text (fraction volume was 4.5 ml). 3-MeAde, 3-Methyladenine; 3-MeGua, 3-methylguanine; 7-MeGua, 7-methylguanine; Gua, guanine; Ade, adenine; $O^{6}$-MeGua, $O^{6}$-methylguanine; $O$, radioactivity (d.p.m.); $0, E_{260}$.

Table 1. Alkylated purines in DNA from different rat tissues after repeated administration of $\mathrm{N}-\left[{ }^{3} \mathrm{H}\right]$ methyl-N-nitrosourea

Two BD-IX rats received five injections of $N-\left[{ }^{3} \mathrm{H}\right]$ methyl$N$-nitrosourea $(10 \mathrm{mg} / \mathrm{kg} ; 26.3 \mathrm{mCi} / \mathrm{mmol})$ at weekly intervals and were killed 1 week after the final dose. Isolation and analysis of DNA was as described in the text.

\begin{tabular}{|c|c|c|c|}
\hline \multirow[b]{2}{*}{ Organ } & \multicolumn{2}{|c|}{$10^{4} \times \mathrm{Mol} \%$ of guanine } & \multirow{2}{*}{$\begin{array}{c}\text { Ratio } \\
O^{6} \text {-MeGua/ } \\
\text { 7-MeGua }\end{array}$} \\
\hline & $\begin{array}{l}O^{6} \text {-Methyl- } \\
\text { guanine }\end{array}$ & $\begin{array}{l}\text { 7-Methyl- } \\
\text { guanine }\end{array}$ & \\
\hline Brain* & 59.70 & 88.42 & 0.675 \\
\hline Kidney & 13.93 & 61.35 & 0.227 \\
\hline Spleen & 4.86 & 31.21 & 0.156 \\
\hline $\begin{array}{l}\text { Small } \\
\text { intestine }\end{array}$ & 2.79 & 22.25 & 0.125 \\
\hline Liver & 0.45 & 43.72 & 0.010 \\
\hline
\end{tabular}

* In brain DNA, 3-methylguanine was also present $\left(8.7 \times 10^{-4} \mathrm{~mol} \%\right.$ of guanine $)$.

and $O^{6}$-methylguanine in the DNA from these and other tissues are given in Table 1.

The amounts of $O^{6}$-methylguanine in brain, kidney and liver DNA during repeated application of
$N-\left[{ }^{3} \mathrm{H}\right]$ methyl- $N$-nitrosourea over a 5 -week period are shown in Fig. 2. In the brain, $O^{6}$-alkylation of guanine exhibits an approximately linear increase with time. In the kidney, $O^{6}$-methylguanine amounts to about $25 \%$ of that in brain DNA, whereas in the liver no significant accumulation is apparent.

Fig. 3 shows the time-course of $O^{6}$-alkylation when expressed as a fraction of $(N) 7$-alkylation of guanine, complemented with data obtained in previous experiments (Kleihues \& Margison, 1974). In the brain, the $O^{6}$-methylguanine/7-methylguanine ratio increases steadily, whereas in kidney and liver this ratio shows a rapid initial decrease. In the kidney, this is followed by an increase, which tends to reach a plateau after 3-5 weeks.

\section{Discussion}

In the past, several attempts have been made to find a correlation between the tissue-specific carcinogenicity of $N$-nitroso compounds and their ability to alkylate nucleic acids of different organs in vivo. No consistent differences were found to exist in the initial extent of alkylation between target and nontarget tissues (Swann \& Magee, 1968, 1971; Goth \& Rajewsky, 1972; Kleihues \& Magee, 1973), but the

Vol. 148 


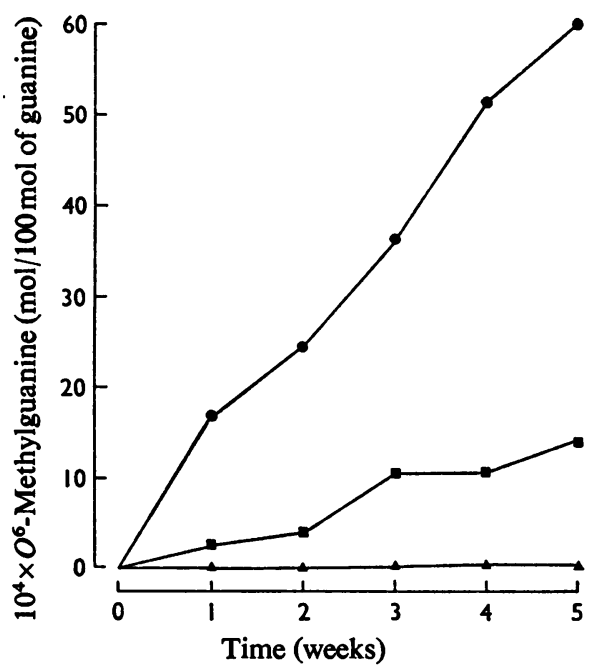

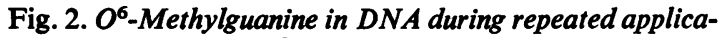
tions of $\mathrm{N}-\left[{ }^{3} \mathrm{H}\right]$ methyl- $\mathrm{N}$-nitrosourea

Animals received one to five injections (each of $10 \mathrm{mg} / \mathrm{kg}$ ) at weekly intervals and were killed 1 week after the final injection. The first dose was given at zero time. Brain (O); kidney $(\boldsymbol{E})$; liver $(\Delta)$.

conclusions reached in these studies were based mainly on the amounts of the major reaction product, 7-alkylguanine. It is now realized that some minor alkylation products, in particular $O^{6}$-alkylguanine, may be more significant in the mutagenic and carcinogenic effect of this group of compounds (see review by Lawley, 1974). Although the relative initial extent of $O^{6}$-alkylation of guanine could explain the differences in the carcinogenic potency of agents such as $N$ methyl- $N$-nitrosourea and methyl methanesulphonate (Kleihues \& Magee, 1973; Lawley, 1974), it does not account for the selective production of tumours in certain organs. There are, however, indications that $O^{6}$-alkylguanine, in contrast with 7-alkylguanine is removed from DNA by an enzymic repair process (O’Connor et al., 1973; Craddock, 1973; Kirtikar \& Goldthwait, 1974) and that the rate of excision may vary in different tissues according to their susceptibility to the carcinogenic effect of alkylating agents (Goth \& Rajewsky, 1974; Kleihues \& Margison, 1974).

This concept is strongly supported by the present experiment. During weekly applications of $N$-methyl$N$-nitrosourea $(10 \mathrm{mg} / \mathrm{kg})$, a dose schedule that leads to the selective production of nervous-system tumours (Druckrey et al., 1965), $O^{6}$-methylguanine accumulated in brain DNA to a much greater extent than in kidney, spleen or intestine (Fig. 2 and Table 1). These latter organs do occasionally develop tumours

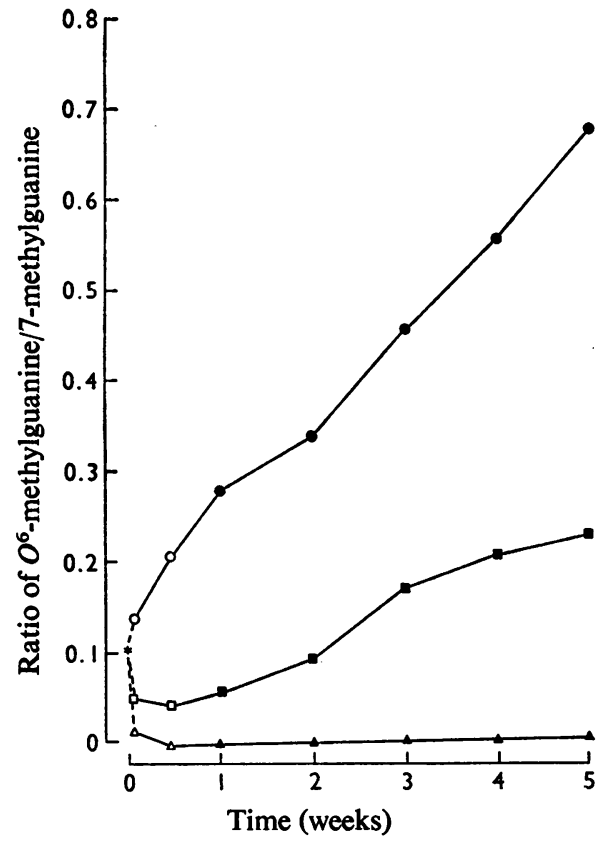

Fig. 3. Changes in the $0^{6}$-methylguanine/7-methylguanine ratio in DNA during repeated applications of $N-\left[{ }^{3} \mathrm{H}\right]$ methyl$N$-nitrosourea

The dose schedule was as in Fig. 2. Brain $(\bullet, 0)$; kidney $(\bullet, \square)$; liver $(\Delta, \Delta)$. The $6 \mathrm{~h}$ and $78 \mathrm{~h}$ values (open symbols) are taken from Kleihues \& Margison (1974). The asterisk at zero time represents the hypothetical initial $O^{6}$ methylguanine/7-methylguanine ratio as found after reaction of $N$-methyl- $N$-nitrosourea with DNA in vitro (Lawley, 1974).

after a single high dose $(60-80 \mathrm{mg} / \mathrm{kg})$ of $N$-methyl- $N$ nitrosourea (Druckrey et al., 1967). In the liver, which is not susceptible to the carcinogenicity of $N$-methyl- $N$-nitrosourea (except after partial hepatectomy; Craddock \& Frei, 1974), the amount of $O^{6}$-methylguanine at the end of the experimental period was less than $1 \%$ of that in brain DNA.

These results can only partially be explained by differences in the rates of cell turnover, since the latter would proportionally decrease the amount of 7-methylguanine: when $O^{6}$-alkylation of guanine is expressed as a fraction of $(N) 7$-alkylation, the differences between the tissues become somewhat smaller, the $O^{6}$-methylguanine/7-methylguanine ratio in cerebral DNA being between three times (kidney) and 60 times (liver) as high as in other organs (Table 1). To a greater extent, the tissue differences seem to reflect the capacity of the various organs actively to remove $O^{6}$-alkylation damage. If $N$-methyl- $N$ nitrosourea is caused to react with DNA in theabsence 
of cellular repair processes in vitro, the $O^{6}$-methylguanine/7-methylguanine ratio is 0.1 (Lawley, 1974). Fig. 3 shows that in liver and kidney this ratio is probably never achieved in vivo owing to a very rapid initial excision of $O^{6}$-methylguanine. The inability of the brain to repair the chemical modification of its DNA may not be restricted to $O^{6}$-alkylation of guanine, since distinct quantities of 3-methylguanine were also found to have accumulated in cerebral DNA (Fig. 1). Alkylation in the (N)3-position of guanine has been observed after reaction of $N$-methyl$N$-nitrosourea with DNA in vitro (Lawley et al., 1972) and in liver DNA after treatment with dimethylnitrosamine in vivo (Craddock, 1973).

The presence of small amounts of 3-methyladenine in brain DNA 1 week after the last injection (Fig. 1) is difficult to explain since this product is released from DNA by non-enzymic hydrolysis, a reaction which proceeds with a half-life of $24 \mathrm{~h}$ at $37^{\circ} \mathrm{C}$ in aqueous solutions in vitro (Lawley \& Brooks, 1963). The amount of radioactive $N$-methyl- $N$ nitrosourea injected should not allow the detection of this base after 7 days if a similar half-life applied to the situation in vivo.

After a single dose of $N$-methyl- $N$-nitrosourea $(10 \mathrm{mg} / \mathrm{kg}), O^{6}$-methylguanine in cerebral DNA decreased by approx. $20 \%$ within 3 days (Kleihues \& Margison, 1974). The present study indicates that this rate of loss is not maintained as part of an exponential decay curve and may therefore reflect the activity of only a minor cell population. The approximately linear accumulation of $O^{6}$-methylguanine in cerebral DNA during a 5-week period of repetitive application strongly suggests that a significant excision of this base does not occur in any major cell fraction of the brain.

The technical assistance of Mrs. U. Winkler and Miss I. Stachelhaus is gratefully acknowledged. G. P. M. was a recipient of a Max-Planck Fellowship.

\section{References}

Craddock, V. M. (1973) Biochim. Biophys. Acta 312, 202-210

Craddock, V. M. \& Frei, J. V. (1974) Br. J. Cancer 30, 503-511

Druckrey, H. (1971) Arzneim. Forsch. 21, 1274-1278

Druckrey, H., Ivankovic, S. \& Preussmann, R. (1965) Z. Krebsforsch. 66, 389-408

Druckrey, H., Preussmann, R., Ivankovic, S. \& Schmähl, D. (1967) Z. Krebsforsch. 69, 103-101

Gerchman, L. L. \& Ludlum, D. B. (1973) Biochim. Biophys. Acta 308, 310-316

Goth, R. \& Rajewsky, M. F. (1972) Cancer Res. 32, 1501-1505

Goth, R. \& Rajewsky, M. F. (1974) Proc. Natl. Acad. Sci. U.S.A. 71, 639-643

Jänisch, W. \& Schreiber, D. (1969) Experimentelle Geschwülste des Zentralnervensystems, V. E. B. Gustav Fischer, Jena

Kirtikar, D. \& Goldthwait, D. A. (1974) Proc. Natl. Acad. Sci. U.S.A. 71, 2022-2026

Kleihues, P. \& Magee, P. N. (1973) J. Neurochem. 20, 595-606

Kleihues, P. \& Margison, G. P. (1974) J. Natl. Cancer Inst. 53, 1839-1841

Lawley, P. D. (1974) Mutat. Res. 23, 283-295

Lawley, P. D. \& Brooks, P. (1963) Biochem. J. 89, 127-138

Lawley, P. D. \& Shah, S. A. (1972) Biochem. J. 128, 117-132

Lawley, P. D. \& Thatcher, C. J. (1970) Biochem. J. 116, 693-707

Lawley, P. D. \& Shah, S. A. (1973) Chem.-Biol.Interact. 7, 115-120

Lawley, P. D., Orr, D. J. \& Shah, S. A. (1972) Chem.-Biol. Interact. 4, 431-434

Loveless, A. (1969) Nature (London) 223, 206-207

O'Connor, P. J., Capps, M. J. \& Craig, A. W. (1973) Br.J. Cancer 27, 153-166

Swann, P. F. \& Magee, P. N. (1968) Biochem. J. 110, 39-47

Swann, P. F. \& Magee, P. N. (1971) Biochem. J. 125, 841-847

Swenberg, J. A., Koestner, A. \& Wechsler, W. (1972) Lab. Invest. 26, 74-85 